\title{
MUSICOLOGY IN ISLAM: A PRELIMINARY STUDY
}

\author{
Saidah Haris@ Harith ${ }^{1}$, PhD \\ Senior Lecturer, \\ Institute of Teacher Education Ipoh Campus, \\ Malaysia
}

\author{
Ganesan Shanmugavelu' ${ }^{2}$, PhD \\ Senior Lecturer, \\ Institute of Teacher Education Ipoh Campus, \\ Malaysia
}

\author{
Hanizah Abdul Bahar ${ }^{3}$ \\ Senior Lecturer, \\ Institute of Teacher Education Ipoh Campus, \\ Malaysia
}

Article DOI: https://doi.org/10.36713/epra5917

\begin{abstract}
The aim of this study is to discuss about Musicology in Islam. The study of music was actively done by Muslim's scholars all over the world. Achieving these aims demands the highest levels of understanding the musicology in Islam and the greatest amount of originality from all contributors. By knowing the history and background of musicology in the Islamic world throughout the centuries, we gain the principle to utilize the talents and abilities of Muslim communities.
\end{abstract}

KEYWORDS: Music, Literature, Devotional, Recitation, Characteristic, Sufi

\section{INTRODUCTION}

No doubt that Islamic art and spirituality of Islam consider music as one of the great significance aspect in the world. There are various stages of Islamic art to study in order to know the flows of the music as a tradition in the Islamic world. As what had been said by Fuat Sezgin, Islam's Golden Age of Science was an extended knowledge from the 8th to the 16th centuries. The word musîq 1 derived from the Greek word which had been used in many theoretical works, whereas in Arabic term, Ghina (song), has been used also for music in secular contexts. Other than that, the terms are used for what a Westerner might call music in folk and sacred contexts.

For the group of Ikhwan al-Safa, the music itself is a spiritual art founded by wise men. It has a strong and varied effects in all souls. It is soothing or exciting, gratifying or grieving. On this account, music is played to calm the sick and insane, to tranquillize a weeping child or to lull him to sleep. Even animals are subject to the effect of music. Music is also played in temples because of the touch of awe it possesses.

According to Abdur Rahman al Baghdadi, music means the art of sound or voice and together with the instruments. Islamic music is known as the Muslim religious music, as sung or played in public services or private devotions. The classic heartland of Islam is the Middle East, North Africa, Iran, South Asia and Central Asia. The indigenous musical styles of these areas have shaped the devotional music enjoyed by contemporary Muslims.

One of the scholars is Hazrat Inayah Khan, who determined the importance of music in the life stated in his book The Mysticism of Sound and Music, and especially in the section of music, Inayah Khan claims that music is called the divine art, while all other arts are not so called. We may certainly see God in all arts and in all sciences, but in music alone, we see God free from all forms and thoughts. The sound alone is free from form". For Inayah Khan, the main purpose of understanding music in life is to reveal the harmony of 
the universe, and show the part that each individual, each creature, he stops play in a symphony. He, then, considered life as music.

Parallel with the idea, Howard Gardner (1980) written a book entitled Frames of Mind. This famous book explained the theory in education. He stated that everybody has the ability in multiple intelligent including linguistic, logical-mathematical, spatial, kinesthetic and musical. From the research, he strengthened the idea of music, where at the beginning stage of a baby, he understands and imitate the sound and melodies all around him.

\section{MUSIC LITERATURE AND CONTRIBUTORS IN ISLAM}

Early in Islamic era music accompanied such events as pilgrimages, weddings and wars. The nature of such music is difficult to reconstruct because it was not written down. However, many of the outstanding Muslim of learning, especially musician and philosophers, were well-versed in music and their theories, such as al Fârâbi (m. 339/950), Ibnu Sînâ (m. 428/1037) and Urmawi.

\begin{tabular}{|c|c|c|c|}
\hline Name & Date of Death & $\begin{array}{l}\text { Major Location of } \\
\text { Life and Work }\end{array}$ & $\begin{array}{l}\text { Main Field(s) of } \\
\text { Relevant Work }\end{array}$ \\
\hline \multicolumn{4}{|l|}{ Ninth century } \\
\hline $\begin{array}{l}\text { Ibn Abû al Dunyâ, Abû Bakar } \\
\text { 'Abdullah Ibn Muhammad }\end{array}$ & $281 / 894$ & Baghdad & $\begin{array}{l}\text { Lawfulness of } \\
\text { sama', musical } \\
\text { instruments }\end{array}$ \\
\hline $\begin{array}{l}\text { Al Kîndî, Abu Yûsuf Ya'qûb Ibn } \\
\text { Ishaq }\end{array}$ & Alter $256 / 870$ & Basrah, Baghdad & Music theory \\
\hline \multicolumn{4}{|l|}{ Tenth century } \\
\hline $\begin{array}{l}\text { Al Fârâbi, Abû Nasr Muhammad } \\
\text { Ibn Muhammad Ibn Tarkhân }\end{array}$ & $339 / 950$ & Aleppo & Music theory \\
\hline $\begin{array}{l}\text { Al Isfahânî , Abû al Faraj 'Alî Ibn } \\
\text { al Husayn Ibn Muhammad }\end{array}$ & $356 / 957$ & Bagdad, Aleppo & $\begin{array}{l}\text { Adab, biography, } \\
\text { songs and song } \\
\text { collections }\end{array}$ \\
\hline \multicolumn{4}{|l|}{ Eleventh century } \\
\hline $\begin{array}{l}\text { Al Ghâzâlî, Majd al Dîn Ahmad } \\
\text { Ibn Muhammad al Tûsî }\end{array}$ & $505 / 1111$ & Tus, Baghdad & $\begin{array}{l}\text { Lawfulness of } \\
\text { samâa }\end{array}$ \\
\hline \multicolumn{4}{|l|}{ Thirteenth century } \\
\hline $\begin{array}{l}\text { Safî al Dîn ‘Abd al Mu'min Ibn } \\
\text { Yûsuf Ibn Fhâkir al Urmawî }\end{array}$ & $693 / 1294$ & Baghdad & Music theory \\
\hline $\begin{array}{l}\text { Ibn Jamâ'ah, Burhân al Dîn } \\
\text { Abû Isaac Ibrahîm Ibnb 'Abd } \\
\text { al Rahîm }\end{array}$ & $790 / 1388$ & Dimashq & $\begin{array}{l}\text { Lawfulness of } \\
\text { sama' }\end{array}$ \\
\hline $\begin{array}{l}\text { Ibn Taymiyyâh, Taqî al Dîn } \\
\text { Ahmad }\end{array}$ & $728 / 1328$ & Dimashq & $\begin{array}{c}\text { Lawfulness of } \\
\text { sama' }\end{array}$ \\
\hline \multicolumn{4}{|l|}{ Fifteenth century } \\
\hline $\begin{array}{l}\text { Ibn al Jazârî̀, Shams al Dîn Abû } \\
\text { al Khayr Muhammad Ibn } \\
\text { Muhammad Ibn 'Alî Ibn Yûsûf }\end{array}$ & $833 / 1429$ & Dimashq, Syiraz & Tajwîd al Qur'an \\
\hline \multicolumn{4}{|l|}{ Sixteenth century } \\
\hline $\begin{array}{l}\text { Al Haythâmî, Abu al 'Abbas } \\
\text { Ahmad Ibn Muhammad Ibn } \\
\text { 'Alî Ibn Hâjâr }\end{array}$ & $974 / 1567$ & Cairo, Makkah & $\begin{array}{l}\text { Lawfulness of } \\
\text { sama }^{\prime}\end{array}$ \\
\hline \multicolumn{4}{|l|}{ Eighteenth century } \\
\hline $\begin{array}{l}\text { Shîhab al Dîn, Muhammad Ibn } \\
\text { Isma'il al Hijazi }\end{array}$ & $1238 / 1822$ & Cairo & Music theory \\
\hline
\end{tabular}


In the wake of the Islamic conquests, Arabic music spread rapidly across Islamic lands, although ethnic and regional styles continued. Fortunately, much information about music and musicians of the early centuries of Islam has been preserved in Kitab Al Aghâni. Poetry for instance, slowly being inseparable from music throughout Islamic history and art. In the early period of Islam, Kitâb al-Âghânî "Book of songs", of Abu 'l-Faraj al-Isfâhânî (d-356H) elucidate the attractiveness of Islamic poetry, music and art, dates to the fourth/tenth century and it is in this period that maqâm develop as a theory and a practice of art music by way of a synthesis of Arabic and Persian forms.

Another famous contributor towards music was Al Mas'udi (d-345H), through his book Murûj alZahab wa Ma'âdin al-Jawâhir. Both scholars, alIsfâhânî and al-Mas'udi, were in the same century, writing music and its development especially in the world of Arab. Their writings include the history of music, types of music, books related to music, the religious perceptions towards music, and the beautifulness of music and biography of musicians. Moreover, these contributors were actively found in the ninth century to the end of the nineteenth century. It is also a great prove that music in Islam had been developed throughout the century.

The Abbasids were influenced by the Qur'anic injunctions and hadith too. The Islamic Golden Age was soon inaugurated by the middle of the $8^{\text {th }}$ century by the ascension of the Abbasid Caliphate and the transfer of the capital from Damascus to the newly founded Baghdad. Disciplines other than our ownanthropology, ethnomusicology, performance studieshave long known that music is at the heart of both religion and culture. The most famous and well known book at the beginning of the tenth century is written by Abu Faraj al Isfahani (d. 356/967), entitled Books of Songs. The book happens to be the primary source of other scholars in extracting knowledge and information of music up in this era.

A remarkable system regulated cantillation (talhin) with respect to the law of phonetics and preferred diction of musical aspects in reciting /cantillation of Quran in musical melodies of the people from Nejd, region of Arabia, as he preferred the preIslamic simple musical forms of huda and rakbani, with pauses which became a major trait of Quranic cantillation (tarannum). Holy Prophet had recourse to old Arabic tunes used in classical recitation / cantillation of poetry, together with classical poetic rules of prosody which was expressed by Ibn al-'Arabi: "the Prophet Muhammad wanted Quran to be an exclusive passion to replace styles that all chanters were accustomed to singing during that period in time.

Further studies on the music theory were found in the eleventh and twelve centuries. Even though there were plenty of studies in these subjects, the writer stated only several works related to Handasah al Sawt. This is because the other field of music which studied by various scholars in the world were too wide and far from the discussion. The following are the contributors of the lawfulness of sama' and other closely related field.

Noticeably, the study of music was actively done by Muslim's scholars and all over the Muslim's world, especially in the area of Baghdad and Dimashq. Most probably, the development of knowledge and information at that time spread widely in these areas, especially in Abbasid period, where the Sasanid and Byzantine music being adopted into Abbasid's culture. Besides all these forms of music, one must mention the major classical traditions of traditions of music in the Islamic world such as the Persian, Andalusian, Arabic of the Near East, Turkish, and North Indian traditions which have survived to this day.

According to Francis Robinson, in the medieval Islamic World, as elsewhere, music was understood in the broader context of correspondences. Then, continue with Al Farabi (d. 950) and Ibn Sina (Avicenna, 980-1037), they examined music more as a science in our understanding of the word, ignoring cosmology and numerology. Lawfulness of Samoa' was considered as one of the literary works besides music and songs. To understand music and song specifically in musical of Islam is much easier by possessing the knowledge through the lawfulness of sama'. Lawfulness of sama', is related to the concept of art of sound. According to Lamya al_Faruqi, in her writings, she upgraded the concept as Handasah al Sawt or known also as "sound architecture". In her findings, genres are placed on continua between nonmusical and music, and legitimate and illegitimate.

Lamya points out that, sensuous music associated with unacceptable contexts is considered illegitimate (harâm), and is labeled as music. Qur'anic chant (qira'a/ nagham/tarannum), other religious chants, such as the adhan, chanted poetry with noble themes (shi'ir), family and celebration music (lullabies, women songs, wedding songs)," occupational" music(caravan chants, shepherd's tunes, work songs, and military music are all considered legitimate (halal), and labeled as non musical. On the other hand, the vocal and instrumental improvisations, serious metered songs, some instrumental music, non-Islamic origins or music related to pre-Islamic origins are considered music. However, it remains controversial, either 
forbidden or discouraged in Islamic law (al-Faruqi, 1985).

The spread of Islamic music could be seen throughout the Muslim's world, especially in the Arabian and Persian people. Most of the writing, studies and practices of Islamic music or lawfulness of some' were developed in Baghdad, Cairo, Dimashq, Makkah and Istanbul as early as the ninth century. Baghdad was known as the center of knowledge and the city of information and philosophy at that time. Consequently, the tradition of learning and researching the Islamic musical knowledge, actively found in that area. After several centuries, the data showed that there were some contributors appeared in another region or countries such as in Istanbul and India.

In the early $16^{\text {th }}$ century, the Safavid dynasty took place. Here, the development of music in Islam also being continued. They assumed being controlled in Persia. Therefore, at this era, the music was being played even though in the small assemble through a single singer or several instrumentalists who alternate solo vocal and instrumental passages. These activities enhanced the development of music in Islam throughout the centuries.

According to Syed Muhammad Naquib al Attas, he argues that Islam is the unique religion with the al-Dîn concept which is not the same as in other religion. Even though the meaning of al-Dîn is religion, Islam has its rules and regulation that differ to any other religion in the world. It is not as the same as the Western imagined about religion. Therefore, the religion itself must be the main basis of human life. Consequently, in the matter of music, they will not accept any music that leads to negative impact and out of the Islamic guidelines.

According to Mustafa al 'Adâni, music is the way to close to the Almighty God, music also part of the secret way to create the feeling of 'taubah'/ be repentant. There is plenty of music in the human feelings, secret music, heart music, iman and music, light of music and many more. All of this music is the real and unique music in everyone's life. No doubt, the lyrics from the music and songs are normally come from the shi'ir. The Arabian people tend to express their feelings and love through shi'ir. Thus, in showing love towards God, beliefs to the God, they also use music to deliver the feelings.

\section{MUSLIM DEVOTIONAL RECITATION AND MUSIC ACCORDING TO SUFI}

There is an ocean of celestial music related to Sufism, music which varies from other, especially in Turkey and Indo-Pakistan subcontinent, primarily among the Malawis and Chistîs. This type of music overflows in the community of believers on certain occasions such as the anniversary of the great saints. This is directly a practice and religious character of Sufi traditions.

Sufism engaged in ritualized dhikr ceremonies. Each order or lineage within an order has one or more forms for group dhikr, the liturgy of which may include recitation, singing, instrumental music, dance, meditation and trance. The Sufi has used music not as an amusement, but to purify their heart towards God. They love music and called this purification activity with Giza-e-Ruh means food of the soul. Why music? Because music is made of vibrations, and there are secret messages spread in the vibrations.

In Pakistan, Sufi religious music is known as Qawwâli, derived from the word qawwal usually used in Pakistan and Azerbaijan.It is one of the popular activities as a musical genre and performances may attract those who want to hear virtuoso singing rather than contemplate the divine. For Sufis, they trained their heart in feeling. All feelings come in one heart, to feel the devotion and praise, the sorrow, the repentance, the sadness, the mistakes one makes and all feelings that arouse in man's heart. But if the reciting in a melodious voice is done in an artificial manner, with special training and musical rhythms, this is something which the salaf despised, and which they criticized and condemned.

The Sufi's world is full of mystery and extraordinary understanding. Music for them has a multiple meanings in the life. For instance, Hazrat Inayah Khan, he tends to admit that every single occupation, such as gardening, farming, painting and poetry as a music. The exhaling and inhaling of the breath also like a rhythm in the daily life. He claimed that Sufis know better in the art of sound and they know about the past, present and future through the direction of sound. After all, Sufi has used music not as an amusement, but as pure, as prayer to God.

\section{HANDASAH al SAWT OR THE ART OF SOUND}

All of this genre in Islamic musical tradition being simplified and categorized by the famous author of music in Islam, Louis Lamya al Fâruqi as Handasah al Sawt. Her theory defines that, the art of voices in Islam, such as tarannum is related to the Handasah al Sawt. The term musiqa has never included those genres of sound art which were wholeheartedly approved and fostered by the culture, e.g., Qur'anic chant, the adhan, the pilgrimage chants, madhih or chanted poetry (syi'ir). Therefore, she advocated the use of a new expression, handasah al sawt. She came out with a model of the core characteristics of Handasah al Sawt 
in her book, entitled the cultural Atlas of Islam. The following is the model simplified to explain Handasah al Sawt from her point of view. This designation would cover all the forms of sound art, and thus more truly equate with the term "music" and its cognates in other
European languages. It is with that expression and an appreciation of the wide meaning which it implies that this presentation continues.

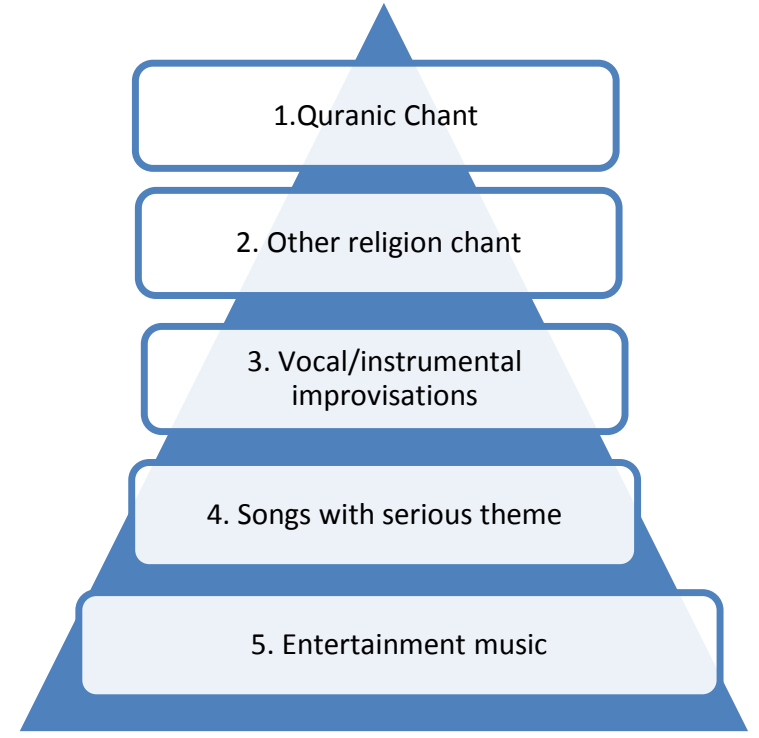

Diagram 2:Genre relevance to the core characteristics of Handasah al Sawt

The upper level of this diagram indicates the Quranic chanting. It is the essence and the heart of the sawti tradition, showing that the chant of sacred text in Islam is the main carrier and purest form of the core characteristics of handasah al sawt. The songs of Qur'anic chanting will always give a great impact towards the listeners, not the same as the other music impact on the heart of the individual. His model system of classical Arabic maqâmat applied in contemporary mujawwad Qur'an recitation derives from a musical tradition of improvisational performance. In order that the revelation is not associated to the human artistry, Quranic reciters are required by law to improvise melodically. The sensation, passion, enthusiasm and feeling will lead to improve individual spiritual, emotional, life to become piety to Islam and Allah.

Next, the level which designates the importance of the chants associated to adhan the call to prayer or for the pilgrimage and also included the pitched recitation of the Prophet Muhammad ( madih). One of the beautiful sung in Islam is the call to prayer (al-adhân), it continuously becomes a symbol to call Muslims and alert them to pray. The type of music that always been implemented by Muslims throughout the world is of melodic strains with the sweet voice during a call to prayer, for every newly born baby boy this called as al-adhân while Iqamat is to be practiced when a baby girl is born. The melody and intone is different from one muazzîn to another.

Wherever there is a mosque, one may hear the adhân regularly five times a day from a minaret or a loudspeaker attached to the main building. People may experience differing the adhân in other contexts such as broadcast on radio or television, or from a recording on an alarm clock, or even in their handphone. The sound from adhân is also considered as song because of the beautiful melody. However, not all scholars and people accepted al-adhân as a song.

These sawti representations reveal a level of correspondence to the main characteristics in Islamic aesthetic creativity only slightly less consistent than qira'ah. These activities had been performed in the Muslim world since the time of the Prophet and continue to perform in the public gathering, in the mosque and the home, at religious occasions as well as other times. Among them are the na't or na'tiyah of Afghanistan, the marhaban, barzanji, rebanah or kompang hadrah, and rodat of Malaysia, and the cultures of Turkey, namely na'at, miraciye and mevlit, the marsîya and $s \hat{z} z$ of Pakistan, which all these being commonly known in those lands with that name.

For the third level, it refers to the instrumental and vocal improvisations for instance the taqâsim, layâli, and qâsidah of Turkey and the Mashriq, the avaz of Iran, the syakl of Afghanistan, the dairah and 
istikhbar of the Maghrib, jinjin of the Hausa of West Africa, and sayil or bâqat vocal music in Southeast Asia. Here, the regional diversity tends to be more frequent and pronounced in both vocal and instrumental examples. Other than that, the beginning of the art in Islam, related to voice is syi' ir. Syi' ir is a poem, sometimes combined with rhythm and rhyme. Syi'ir also considered as the vocal improvisations of the Muslims people since many period. It was also the early Arab poet, and as the early poetical productions, therefore, is of peculiar important as source material for the study of pre-Islamic Arabian life and Bedouin character. Speaking about rhythm and rhyme automatically discuss about sound. Rhythm is the stress and non-stress of sound regularly. Rhyme is the similarity of sound. Famous singer of the Arab world is the late Umm Kalthum. She had various attractive syi'ir and beautiful voice in singing the poem.

Qasîdah is another way of reciting poetry melodiously which contains praises to Prophet Muhammad and companions. It can be explained as the epic religious poetry accompanied by percussion and chanting. Another tradition practiced by the Muslim societies is a performance of singing at regional praises of Muhammad the prophet during his birthday. It is especially dedicated to Rasulullah, and to show love towards the Prophet. It is called Mawlîd music.

Unexpectedly, qasidah was actually having been practiced as the poetry of the pre-Islamic age arose in connection with tribal wars and took the form of qasidah, or ode. At that time, there were some 120 odes composed by lesser lights and compiled by al Mufaddal al Dabbi (d.about 785) of Baghdad, entitled al Mufaddaâliyât, at the instance of the Abbasîd caliph al Mansur for the instruction of his son and successor. A number of pre-Islamic anthologies and poetical fragments have been preserved in two other major works: Diwan al Hanâsah (Fortitude) edited by Abu Tammam, who flourished also in Baghdad, under the caliph of al-Ma'mun and died about 845; and in Kitab al Aghani (Book of Songs), a veritable thesaurus of Arabic literature, written by Isbahani, or al-Isfahâni (c.897-967), a Persian.

The scholars and Muslim thinkers and those who preserve and maintain the stretch of religion must be firmly blocked, and block anyone who tries to read the Qur'an accompanied by music, like singing the Qasîdah. So they have participated keeping scripture from destruction. "Verily, We it is who sent down the Qur'an, and in fact we actually take care of". [Al Hijr:9] and, [Al-Hijr: 9]. And when recited to them Our verses are real, the people who do not expect the meeting with Us say: Bring a Quran other than this or change it ". Say: "It is not for me to replace the part myself. I do not follow except what is revealed to me. Verily I fear if disobey my Lord, the torment of a Great Day (of Resurrection)". [Yunus: 15]

According to Jamal D. Rahman, for the state of Indonesia, there was one of the famous qariah and practitioner of qasidah is Rofiqoh Darto Wahab. She was one of the wonderful qariah as well as excellent in reciting qasidah, which relates to the songs and Islamic musical tradition. This tradition being claimed as one of activities held during the life of Prophet Muhammad (peace be upon him) until nowadays. Another example is the qasidah in Banten,Indonesia, namely the group of qasidah Saraya (rhythm) which use to play together the tune and ketimpring or fly (a qasidah tool made of wood, leather and metal as kecrek) shaped drums had been practiced since long ago.

Another famous musical recitation practice of Islam in Southeast Asia is called "The Barzanji". It became well-known in Southeast Asia (around the nineteenth century), as the most popular texts for nonQur'anic Arabic recitation. Anne M. Gade has written in her paper that the original Barzanji text, Al-'Iqd alJawahir, was composed by Ja'far b. Hasan b. Abd alKarim b. Muhammad al-Barzanji (1690-1764), and it narrates events in the Prophet's life (especially his birth); it also includes sections of praise. In contemporary Indonesia, four readings were often found bound together as a single "Barzanji" text: Mawlid Diba'I, the Barzanji (in several variants), Sharif al-Anam, and the Burdah (or "Mantle Ode" of Al-Busiri [1213-96]).

Until the early 1990's, it seemed to many that Barzanji recitation was dying out across the archipelago. Recitation of the Mawlid has been heatedly contested at times in the Muslim world as a Sufi "innovation"; the controversy led to conflict in Indonesia in the early twentieth century. By the mid1990s, however, a Barzanji revival was underway (surprising even many Barzanji readers themselves).Cassettes were beginning to appear, to expressed amazement of some who have never associated the "traditional" context of Barzanji reading with a commodity like a cassette".

At the fourth category, this refers to the songs with the religious themes such as the qasidah of Malaysia, the ghazal of Iran-Central Asia and the Indian subcontinent, the ilâhi, nefes and sugul of Turkey, the muwanshah dini of the Mashriq, nasyid of the Southeast Asia. These activities are performed normally in groups of female or male or even the combined group of male and female. Sometimes, they use the instrument and sometimes no percussion is needed in performing it. The main idea of these groups is to convey messages of the songs in a beautiful way 
of single melodic line simultaneously performed by all voices.

Meanwhile, the love lyric (ghazal, or gazel) was established as an independent art by 'Umar ibn abi Rabiah(d. about 719) of Mecca, who specialized in enhancing love to beautiful damsels pilgrimaging in the two holy cities of Arabia, and expressed his passion in the language of exquisite felicity. The most famous ghazal at that time was the Platonic love which became the theme of several poetical romances by them. Majnun and Layla became the hero and heroine of a cycle of numberless Arabic, Persian, Turkish and other Islamic language tales extolling the power undying love.

Another part of music expression found in Islam is nasyîd. Nasyîds are ethical, moral, religious songs sung in various melodies by some Muslims of today without any musical instruments or with percussion instruments which allowed in Islam. The difference of nasyîd from other songs in the world is the way of singing it. The group of nasyîd performs in a polite manner, with a simple, moral, religious lyrics and melodies. Most of the lyrics are not from the Qur'anic verses or Hadith.

In the fifth level, it indicates the genres of the secular themes which undoubtedly been influenced by the Qur'an and the musical carried by Muslim travelers, settlers, and pilgrims. Actually, the level distinguishes more on the usual practice of the Muslims in the world, therefore, some of the songs or music is mixed and related to one another.

\section{CONCLUSION}

To conclude the discussion in this chapter, the primary idea is to elaborate the frame of chanting in the world civilization. It is a big challenges to discover the real picture of these chanting activities. However, above explanation should be taken into account in understanding the development and achievement of musicology activvities related to Islam.

\section{REFERENCES}

1. Ab Rahman, A., Zakaria, M.A., Shakor, M.F.A., Nordin, N.S. and Rahmat, N.A.S., 2020. Sorotan literatur kajian kurikulum pendidikan Islam pelajar orang kurang upaya (Oku) Di Malaysia. Syariah and Law Discourse, 1(1), pp.25-33.

2. Alias, U.K., Ishak, H. and Mohamad, S., 2019. Kaedah-kaedah bacaan al-Quran dalam kalangan orang kurang upaya pendengaran. Al-Turath Journal Of Al-Quran And Al-Sunnah, 4(2), pp.5967.

3. Ariffin, Z., 2006. Kerjaya untuk orang kurang upaya. PTS Professional.
4. Aziz, N.A.B.A., Jaafar, N.B., Hashim, M. and Saleh, M.H., 2018. The memorisers of the Al Qur'an among visual impairment scholars.

5. Aziz, N.A.B.A. and Jaafar, N., 2018. Penguasaan pembelajaran Al-Qur'an berbantukan aplikasi multimedia interaktif smart Iqra': Kajian di sekolah kebangsaan pendidikan khas Alma, Pulau Pinang. Journal of Quran Sunnah Education \& Special Needs, 2(2), pp.24-36.

6. Bakar, N.A.L., 2017. The challenges among people with visual disabilities in implimenting sholat. AlHikmah, 9(2), pp.3-15.

7. Chek, Y. and Mohamad, S., 2016. Sumbangan Darul Quran (Jakim) terhadap pengajian al-Quran dalam kalangan orang kurang upaya penglihatan. Al-Turath Journal of Al-Quran And Al-Sunnah, 1(2), pp.25-33.

8. Hajarul Bahti, Z., Ab Halim, T., Norshidah, M. S., \& Mohd Huzairi, A. (2014). Students' attitudes towards learning al-Qur'an recitation and its relationship with the mastery of reading the alQur'an among visual impaired students in Malaysia. In International Conference on Economics, Education and Humanities, Dec (pp. 10-11).

9. Hazlin Falina, R., Safura, A. S., Norazia, A. W., \& Nurzakira Afnee, Z. (2015). Kesedaran golongan majikan terhadap orang kurang upaya (OKU) di Malaysia: Melalui Perspektif Media (Awareness of Employers towards People with Disabilities [PWD] in Malaysia: From Media Perspective).In Proceeding of the 2nd International Conference on Management and Muamalah 2015 (2nd ICoMM), 192-199, e-ISBN: 978-967-0850-25 (Vol. 2).

10. Ibrahim, N., Raus, N.M., Rasdi, N.A., Jaafar, N., Alias, N., Khosim, N. and Ghazali, N.M., 2012. Modul pengajaran Al-Quran Braille: Tinjauan Awal.

11. Lokman, R. A. (2009). Kesan bimbingan kelompok berstruktur model realiti terhadap kawalan kendiri dan motivasi belajar dalam kalangan pelajar salah laku disiplin (Doctoral dissertation, Fakulti Sains Kognitif dan Pembangunan Manusia, Universiti Pendidikan Sultan Idris).

12. Mokhtar, \& Alias, A. (2003). Isu pengajaran dan pembelajaran pendidikan Islam pelajar berkeperluan khas. Prosiding Wacana Pendidikan Islam:

Perkaedahan pengajaran pendidikan Islam.

13. Mohd. Ali Abu Bakar, Seni lagu al-Qur'an di Malaysia (Kuala Lumpur: Dar al-Fikr, 1997),

14. Mohd Najib, A. R. (2006, August). Developing human capital: Towards achieving service beyond the ordinary. In Speech presented for the 11th Civil, Service Conference, National Institute of Public Administration, Bukit Kiara, Kuala Lumpur.

15. Razuan, S.R.A., Raus, N.M., Hashim, M., Rasdi, M.N.A., Yusoff, A.M., Ja'afar, N. and Muhamad, N.A.F., 2019. Pendidikan al-Quran bagi OKU: pengalaman pusat penyelidikan Ibnu Ummi 
Maktum (UMMI). AL-'ABQARI: Journal of Islamic Social Sciences and Humanities, pp.78-98.

16. Rossett, A., \& Garbosky, J. (1987). The use, misuse, and non-use of educational technologists in public education. Educational Technology, 27(9), 37-42.

17. Rosli, H.F., Mahmud, W.A.W. and Mahbob, M.H., 2016. Peranan media sebagai alat kesedaran sosial dalam kalangan orang kurang upaya di Malaysia. Jurnal Komunikasi: Malaysian Journal of Communication, 32(2).

18. Saad, S., 2005. Komitmen dan peranan guru dalam pelaksanaan pendekatan pendidikan Inklusif di Malaysia. Seminar Kanak-Kanak Bermasalah Emosi, Kementerian Pelajaran Malaysia, Putrajaya.

19. Saidah, H. (2018). Pengajian taranum al-Quran di Institut Pendidikan Guru Malaysia (IPG): Kajian aplikasi kaedah pengajaran qari di Malaysia/Saidah Haris@ Harith (Doctoral dissertation, University of Malaya).

20. Shahril Marzuki, \& Habib Mat Som, (1999). Isu pendidikan di Malaysia: sorotan dan cabaran/Shahril@Chari Marzuki, Habib Mat Som.

21. Sidek Mohd, \& Ahmad, J. (2005). Pembinaan modul: bagaimana membina modul latihan dan modul akademik. Penerbit Universiti Putra Malaysia.

22. Wood, J. W. (2002). Adapting instruction to accommodate students in inclusive settings. Prentice Hall.

23. Vygotsky, L. S. (1967). Play and its role in the mental development of the child. Soviet psychology, 5(3), 6-18. 